\title{
Mekanisme Kerja Benalu Teh pada Pembuluh Darah
}

\section{Mechanism of Tea Mistletoe Action on Blood Vessels}

\author{
Nour Athiroh $A S^{1}$, Nur Permatasari $i^{2}$ \\ ${ }^{1}$ Jurusan Biologi Fakultas MIPA Universitas Islam Malang \\ ${ }^{2}$ Laboratorium Farmakologi Fakultas Kedokteran Universitas Brawijaya
}

\begin{abstract}
ABSTRAK
Secara garis besar ada dua jenis penatalaksanaan terhadap hipertensi yaitu menggunakan obat-obatan dan non obat. Adapun penatalaksanaan secara non obat, salah satunya dengan terapi herbal dengan memanfaatkan benalu teh dari famili Loranthaceae misalnya (Viscum album, Dendrophtoe pentandra (L.) Miq, Scurrula parasitica, Scurulla oortiana, dan Macrosolen javanus) yang berpotensi sebagai antihipertensi (vasodilator). Mekanisme kerja dari flavonoid benalu teh sebagai vasodilator karena peran otot polos dan endotel pembuluh darah. Pada umumnya pengobatan hipertensi yaitu pada organ target pembuluh darah (sistem vaskular). Flavonoid benalu teh dalam hal ini quercetin mampu bekerja langsung pada otot polos pembuluh arteri dengan menstimulir atau mengaktivasi Endothelium Derived Relaxing Factor (EDRF) sehingga menyebabkan vasodilatasi. Beberapa penelitian tentang pengaruh flavonoid tanaman teh pada fungsi endotel bahwa kandungan dari flavonoid yaitu polifenol dapat meningkatkan aktivitas dari Nitric Oxide Synthase (NOS) pada sel endotel pembuluh darah. Quercetin mempunyai potensi meningkatkan produksi Nitric Oxide (NO) di sel endotel. Zat aktif tersebut mampu mensintesa NO dalam endotel dan berdifusi secara langsung ke otot polos selanjutnya merangsang guanylate cyclase untuk membentuk cGMP sehingga terjadi vasodilatasi. Kemungkinan benalu teh bersifat sebagai antagonisme kompetetif reseptor $\alpha_{1}$ sehingga tidak terjadi aktivasi reseptor $\alpha_{1}$. Diduga benalu teh menghambat kanal $\mathrm{Ca}^{2+}$ sehingga tidak terjadi peningkatan $\mathrm{Ca}^{2+}$ intrasel dan terjadi defosforilasi MLC akhirnya tidak terjadi kontraksi pembuluh darah arteri. Benalu teh mampu menghambat kontraksi arteri, karena adanya peran endotel pembuluh darah. Secara klinis, Endothelial Progenitor Cell (EPC) dapat memperbaiki kondisi penyakit yang diawali dengan kerusakan sel endotel, misalnya hipertensi. Flavonoid dari benalu teh mampu memperbaiki disfungsi endotel melalui mekanisme reendotelisasi.
\end{abstract}

Kata Kunci: Benalu teh, nitric oxide, otot polos, sel endotel, vasodilator

\begin{abstract}
There are two types of hypertension treatment that are pharmacologic and non pharmacologic treatments. Non pharmacologic treatments such as herbal teas using the mistletoe from the family Loranthaceae (Viscum album, Dendrophtoe pentandra (L) Miq, Scurrula parasitica, Scurulla oortiana, and Macrosolen javanus) is potential as anti hypertension (vasodilator). The mechanism of tea mistletoe action in the blood vessels occur in smooth muscle and endothelial target organ. Flavonoids of tea mistletoe, in this case quersetin, is able to work directly on the smooth muscle of blood vessels to stimulate or activate Endothelium Derived Relaxing Factor, causing vasodilatation. Flavonoids such as polyphenols can increase the activity of Nitric Oxide Synthase (NOS) in vascular endothelial cells. Active substances can be diffused directly and synthesize Nitric Oxide (NO) in smooth muscle and endothelial further stimulate guanylate cyclase to form CGMP cause vasodilation. Mistletoe of tea as competitive $\alpha_{1}$ receptor antagonism. Mistletoe of tea inhibit the Ca ${ }^{2+}$ channel so intracellular $\mathrm{Ca}^{2+}$. Thus, putative putative activity of mistletoe as competitive alpha 1 receptor antagonism does not increase and MLC become dephosphorilation. The possibility of the mechanism of tea mistletoe inhibit flavonoid antioxidants can stimulate the production of NO that causes relaxation of blood vessels. Mistletoe of tea can inhibit the contraction of the arteries, through role of the endothelium. Clinically, endothelial progenitor cells can improve the condition of disease that begins with endothelial cell damage, such as hypertension. The mistletoe of tea flavonoids has a potential effect to improve endothelial dysfunction through a reendothelial mechanism.
\end{abstract}

Keywords: Endothelial cells, mistletoe, nitric oxide, smooth muscle, vasodilator

Jurnal Kedokteran Brawijaya, Vol. 27 No. 1, Februari 2012; Korespondensi: Nour Athiroh AS. Jurusan Biologi Fakultas MIPA Universitas Islam Malang.JI.MT. Haryono 193 Malang Tel.(0341) 551932Email:nur_athiroh_mlg@yahoo.co.id 


\section{PENDAHULUAN}

Perubahan hemodinamika akan mempengaruhi kondisi pembuluh darah, dapat mengakibatkan terjadinya kontraksi atau relaksasi otot polos pembuluh darah sehingga terjadi perubahan tekanan darah. Salah satu penyakit pembuluh darah yang sering menjadi problem klinisi adalah hipertensi. Hipertensi diakibatkan oleh peningkatan salah satu atau lebih dari berbagai komponen.

Pengendalian tekanan darah secara logis dan ideal adalah dengan cara menurunkan Systemic Vascular Resistance (SVR) dan mempertahankan Cardiac Output (CO) dan perlu diimbangi dengan regulasi tonus pembuluh darah (1). Secara garis besar ada dua jenis penatalaksanaan terhadap hipertensi yaitu menggunakan obat-obatan dan non obat. Salah satu organ target pada pengobatan hipertensi yaitu pada pembuluh darah (sistem vaskular). Sistem vaskular yang berperan adalah otot polos dan endotel yang menyebabkan vasodilatasi dan vasokonstriksi. Pada dasarnya vasodilatasi ditentukan oleh relaksasi otot polos yang melibatkan fungsi endotel. Endotel mensintesa Nitric Oxide (NO) sebagai pemicu terjadinya relaksasi otot polos pembuluh darah (1). Dipasaran banyak ditemukan obat antihipertensi yang bekerja di otot polos dan endotel. Obat antihipertensi yang bekerja di otot polos misalnya $\alpha_{1}$ blocker fenoksibenzaminyang memblok reseptor $\alpha_{1}$ dan $\alpha_{2}$ pada otot polos arterioll dan vena sehingga menimbulkan vasodilatasi (2). Beberapa obat yang juga dipakai sebagai terapi hipertensi antara lain, diuretik, penghambat syaraf adrenergik, a1 blocker, 6 blocker, Angiotensin Converting Enzyme Inhibitor (ACEI), Angiotensin-II-bloker, antagonis kalsium, vasodilator.

Terapi non obat meliputi penurunan berat badan, olah raga secara teratur, diet rendah lemak dan garam, dan terapi komplementer. Penanganan secara non-obat sangat diminati oleh masyarakat karena sangat mudah untuk dipraktikan dan tidak mengeluarkan biaya yang terlalu banyak. Terapi komplementer bersifat terapi pengobatan alamiah diantaranya adalah dengan terapi herbal. Terapi herbal banyak digunakan oleh masyarakat dalam menangani penyakit. Obat herbal telah diterima secara luas hampir diseluruh negara di dunia. Menurut WHO, negara-negara di Afrika, Asia, dan Amerika Latin menggunakan obat herbal sebagai pelengkap pengobatan primer. Bahkan di Afrika, sebanyak $80 \%$ dari populasi menggunakan obat herbal untuk pengobatan primer. WHO merekomendasikan penggunaan obat tradisional termasuk herbal dalam pemeliharaan kesehatan masyarakat, pencegahan, dan pengobatan penyakit, terutama untuk penyakit kronis, penyakit degeneratif, dan kanker. WHO juga mendukung upaya-upaya dalam peningkatan keamanan dan khasiat dari obat tradisional (3).

Beberapa jenis herbal dari kelompok benalu teh dari famili Loranthaceae juga berpotensi sebagai antihipertensi. Berbagai riset telah dilaporkan tentang peranan benalu sebagai antihipertensi, bahwa Viscum album famili dari Loranthaceae merupakan benalu semiparasit pada tanaman teh berpotensi untuk antihipertensi (hipotensi) dan anti kanker $(4,5)$. Hasil penelitiannya mengindikasikan bahwa pada perlakuan herbal V.album terhadap pasien hipertensi terjadi penurunan tekanan darah selama 3-5 minggu (5). V. album mengandung viscotoxin, phoratoxin, dan quercetin, yang berperan sebagai vasodilator (6). V. album menyebabkan terjadinya penurunan tekanan darah pada hewan uji tikus dengan model hipertensi $(7,8,9)$ Disamping itu pula salah satu fungsi dari benalu Scurrula parasitica yang sudah dikeringkan berguna untuk menurunkan tekanan darah tinggi.

Jenis benalu teh yang lain yaitu Scurulla oortiana. Ekstrak kasar benalu teh (S. oortiana) dan benalu jambu mawar (Macrosolen javanus) mampu menurunkan kontraksi pembuluh darah arteri ekor tikus terpisah, namun mekanisme pastinya belum diketahui, sehingga perlu dikaji peran otot polos dan endotel terhadap relaksasi pembuluh darah (10).

Penelitian berikutnya telah melakukan determinasi pada beberapa tanaman di Nigeria dan Nigeria Barat salah satunya adalah benalu Loranthus yang berkhasiat untuk terapi hipertensi. Berdasarkan analisis fitokimia tanaman tersebut mempunyai kandungan seperti; tannin, flavonoid, quersetin, glikosida, alkaloid, saponin, dan inulin, zat aktif tersebut telah dilaporkan mempunyai peranan pada hipertensi (11).

Berdasarkan pemaparan tersebut otot polos dan sel endotel pembuluh darah merupakan kajian yang penting untuk mengetahui mekanisme target kerja obat. Beragam jenis dari benalu teh berperan sebagai antihipertensi atau vasodilator. Artikel ini menjelaskan mekanisme kerja benalu teh terhadap pembuluh darah dalam pengelolaan hipertensi.

\section{TINJAUAN PUSTAKA}

\section{Mekanisme Kerja Benalu Teh pada Pembuluh Darah}

Ekstrak air benalu teh $S$. oortiana mengandung senyawa catechin, phytol flavonoid likosida, dan kafein (12). Hasil penelitian dari tim peneliti Badan Tenaga Atom Nasional Indonesia bekerjasama dengan Prof. Hirotoka Shibuya dari Universitas Fukuyama dan Prof. Dr. Mutsuku Mukai dari Osaka Medical Center Jepang menunjukkan bahwa benalu teh genus Scurulla pada Perkebunan Teh Gunung Mas, Cipanas Jawa Barat dapat diisolasi 16 senyawa penting. Senyawa tersebut antara lain 6 senyawa asam lemak tak jenuh, 2 senyawa xantin, 2 senyawa flavonol glikosida, 4 senyawa flavonol, 1 senyawa lignan glikosida, dan satu senyawa monoterpen glikosida $(13,14)$. Ada tiga komponen senyawa kimia flavonol yang diisolasi dari Scurulla feeruginea yaitu quersetin dan 4"-Oasetilquersetin. Berdasarkan hasil uji fitokimia, kandungan senyawa benalu teh genus Loranthus terdiri dari alkaloid, steroid, flavonoid, saponin, kuinon, dan tannin.

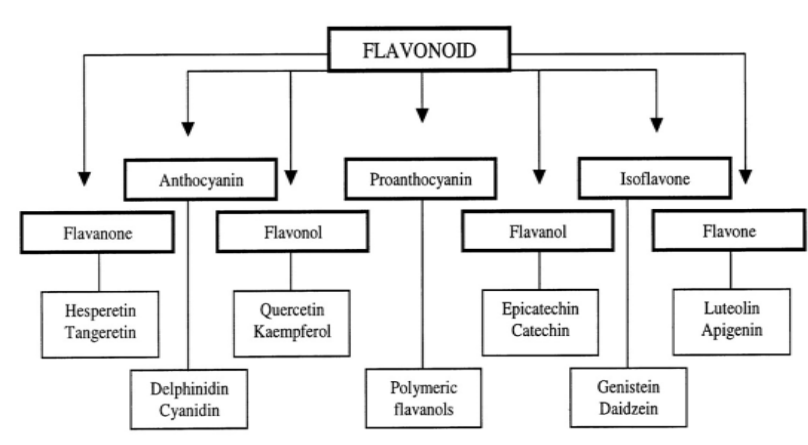

Gambar 1. Klasifikasi flavonoid (15) 
Quersetin jenis flavonoid yang paling banyak terkandung dalam buah-buahan dan sayuran. Hasil riset melaporkan bahwa konsumsi komponen flavonoid bervariasi dari 50 mg sampai 1 gram per orang per hari, dengan dua jenis flavonoid yang terbesar berupa quercetin dan kaempferol (16). Mekanisme kerja dari flavonoid sebagai vasodilator karena peran otot polos dan endotel pembuluh darah. Organ target pada pengobatan hipertensi yaitu pada pembuluh darah (sistem vaskular).

Benalu teh pada umumnya mengandung flavonoid (terdiri dari quersetin, chalcone, dan turunan flavon), terpen (misalnya beta-amyrin, betulinic acid, oleanic acid, betasitosterol, stigmasterol, ursolic acid, lupeol, dan kombinasi ester), amine (misalnya; acetylcholine, choline, histamine, GABA dan tyramine), serta viscotoxins $\mathrm{A} 2, \mathrm{~A} 3$ and $\mathrm{B}$. Benalu teh juga mengandung komponen fenolic termasuk caffeic dan myristic acid, lectins, fatty acids, sugars, and tannins. Zat aktif yang berkhasiat sebagai hiopotensi yaitu acetylcholine, histamine, GABA, tyramine dan flavonoid (13).

Flavonoid benalu teh dalam hal ini quercetin mampu bekerja langsung pada otot polos pembuluh arteri dengan menstimulir atau mengaktivasi Endothelium Derived Relaxing Factor (EDRF) sehingga menyebabkan vasodilatasi. Beberapa penelitian tentang pengaruh flavonoid tanaman teh pada fungsi endotel melaporkan bahwa kandungan dari flavonoid yaitu polifenol dapat meningkatkan aktivitas dari Nitric Oxide Synthase (NOS) pada sel endotel pembuluh darah. Quercetin mempunyai potensi meningkatkan produksi NO di sel endotel (17). Zat aktif tersebut mampu berdifusi secara langsung dan mensintesa NO dalam endotel dan otot polos selanjutnya merangsang guanylate cyclase untuk membentuk cGMP sehingga terjadi vasodilatasi (18). Terjadinya vasodilator kemungkinan karena adanya peran endotel atau otot polos pembuluh arteri $(2,19)$.

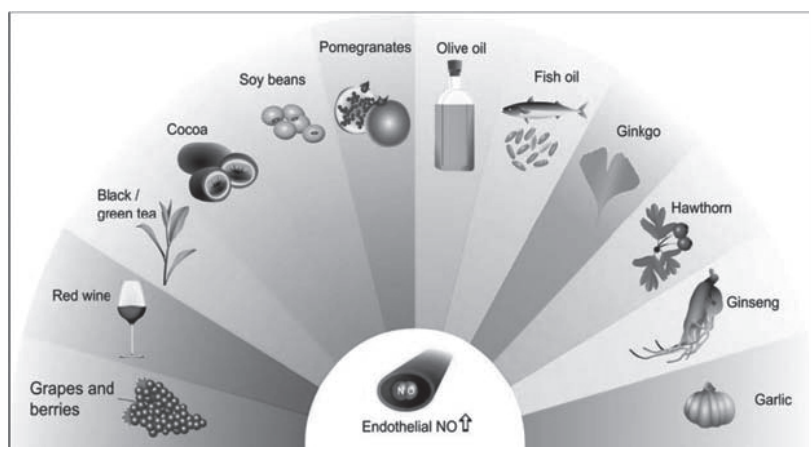

Gambar 2. Peran flavonoid pada berbagai buah dan sayuran terhadap peningkatan ketersediaan NO sel endotel (17)

Hasil penelitian tentang pengaruh epigallocatechin-3gallate yang diperlakukan terhadap preparat ring aorta tikus terpisah yang distimulasi oleh phenylephrine, menunjukkan bahwa polifenol yang terkandung dalam tanaman tersebut meningkatkan relaksasi otot polos pembuluh darah bersama dengan peran endotel. Teh hitam dan polifenol teh hitam akan berpengaruh pada aktivitas NOS endotel dan pada kultur sel endotel pembuluh darah (20). Teh hijau dan teh hitam meningkatkan aktivitas NOS endotel pada sel endotel aorta sapi, demikian juga pada ring aorta tikus (21).

Penelitian secara in vivo menunjukkan bahwa teh hijau dan teh hitam akan meningkatkan relaksasi pembuluh darah pada wanita. Peran flavonoid pada ekstrak anggur bebas alkohol secara nyata menurunkan tekanan darah sistol dan diastol jantung pada model tikus hipertensi (22). Hasil penelitian tersebut juga didukung oleh Negishi bahwa pemberian polifenol teh hitam (3,5 g/L thearubigins, 0,6 $\mathrm{g} / \mathrm{L}$ theaflavins, 0,5 g/L flavonols, dan 0,4 g/L catechins) teh hijau (3,5 g/L catechins, 0,5 g/L flavonols, dan $1 \mathrm{~g} / \mathrm{L}$ flavonoid polimer), secara nyata menurunkan tekanan darah baik sistol maupun diastol pada tikus model hipertensi (23). Penelitian yang telah dilakukan oleh Athiroh $d k k$ tentang efek pemberian ekstrak kasar Scurulla oortiana (benalu teh) dan Macrosolen javanus (benalu jambu mawar) terhadap kontraktilitas pembuluh darah arteri ekor tikus terpisah dengan atau tanpa endotel, menunjukkan bahwa kedua benalu tersebut mampu menurunkan kontraksi pembuluh darah arteri secara invitro karena peran endothel (10).

Pemberian benalu teh pada pasien hipertensi mampu memperbaiki atau mengembalikan fungsi endotel, seperti halnya dengan pemberian $\alpha$ bloker. Benalu teh bersifat antagonisme kompetetif reseptor $\alpha_{1}$ sehingga tidak terjadi aktivasi reseptor $\alpha_{1}$. Pemberian quercetin pada model ekspremen trakea tikus secara in vitro menghambat kontraksi melalui presinaptik dan possinaptik setelah distimulasi oleh listrik dan carbachol (24). Benalu teh menghambat kanal $\mathrm{Ca}^{2+}$ sehingga tidak terjadi peningkatan $\mathrm{Ca}^{2+}$ intrasel dan terjadi defosforilasi MLC akhirnya tidak terjadi kontraksi otot arteri (19). V. album mampu menurunkan kontaktilitas aorta ring tikus setelah distimulasi oleh noradrenalin dan $\mathrm{KCl}$, hal ini dibuktikan dengan adanya pergeseran kurva respon konsentrasi ke kanan. Efek vasorelaksasi terjadi juga melalui NO, hal ini karena NO menghambat masuknya $\mathrm{Ca}^{2+}$. Oleh karena itu, $V$. album sebagai vasodilator melalui stimulasi dari NO melalui jalur guanylate cyclase serta melalui mekanisme $\mathrm{Ca}^{2+}$-dependent. Hipertensi ditandai dengan peningkatan resistensi perifer mungkin karena tingginya $\mathrm{Ca}^{2+}$ dan atau disfungsi endotel. $V$. album sering digunakan oleh rakyat Nigeria untuk pengobatan hipertensi (25). Antagonis kalsium (AK) bekerja dengan cara menghambat masuknya kalsium ke dalam sel melalui chanel-L. AK dibagi 2 golongan besar, yaitu AK non-dihidropiridin (kelas fenilalkilamin dan benzotiazepin) dan AK dihidropiridin (1,4-dihidropiridin). Golongan dihidropiridin terutama bekerja pada arteri sehingga dapat berfungsi sebagai obat antihipertensi, sedangkan golongan non-dihidropiridin mempengaruhi sistem konduksi jantung dan cenderung melambatkan denyut jantung, efek hipertensinya melalui vasodilatasi perifer dan penurunan resistensi perifer (26).

Angiotensin II yang diinduksi oleh aktivasi Jun $N$ - terminal Kinase (JNK) pada kultur sel otot polos aorta tikus dihambat oleh quercetin. Quercetin sangat bermanfaat untuk terapi penyakit kardiovaskular (27). Pada penelitian yang lain menunjukkan bahwa flavonoid teh juga akan menurunkan tekanan darah yang dimodulasi oleh sistem Renin-Angiotensin-Aldosteron (28). Hal ini membuktikan bahwa falvonol dapat menghambat aktivitas AngiotensinConverting-Enzyme (ACE). Data penelitian baik secara invitro maupun in vivo menjelaskan bahwa flavonoid pada teh secara nyata menurunkan tekanan darah pada 
manusia (29) quercetin menghambat angiotensin II (30).

\section{Flavonoid Benalu Teh sebagai Antioksidan}

Pemanfaatan tanaman benalu teh terhadap penanganan hipertensi telah banyak diteliti. Pemanfaatan herbal ini merupakan penanganan secara non obat yaitu melalui terapi komplementer atau pengobatan alternatif. Berbagai hasil riset menunjukkan bahwa benalu teh berkhasiat menurunkan tekanan darah, karena benalu mengandung flavonoid (ref). Flavonoid banyak diteliti efeknya terhadap kesehatan. Senyawa flavonoid dapat berperan sebagai antioksidan alami yang melindungi sistem biologis dan menghambat oksidasi sel dengan cara mereduksi, menangkap oksigen aktif dan radikal bebas terutama superoksida. Salah satu mekanisme kerja dari antioksidan adalah dengan meningkatkan lipid peroksidase pada sel $(15,31)$. Flavonoid sebagai metabolit sekunder berguna untuk memperkuat kapiler darah dan diuretik. Flavonoid juga menurunkan kadar prostasiklin (substansi yang diproduksi oleh sel endotel pembuluh darah) dan kadar leukotrien, sehingga menyebabkan terjadinya vasodilatasi dan menghambat agregasi platelet darah (15).

Salah satu flavonoid yang berkhasiat adalah quercetin. Senyawa ini beraktivitas sebagai antioksidan dengan melepaskan atau menyumbangkan ion hidrogen kepada radikal bebas peroksi agar menjadi lebih stabil. Aktivitas tersebut menghalangi reaksi oksidasi kolesterol jahat (LDL) yang menyebabkan darah mengental, sehingga mencegah pengendapan lemak pada dinding pembuluh darah struktur molekul antioksidan bukan hanya memiliki kemampuan melepas atom hidrogen tetapi juga mengubah radikal menjadi reaktivitas rendah, sehingga tidak terjadi reaksi dengan lemak. Antioksidan terdiri atas antioksidan endogen yang dihasilkan oleh tubuh sendiri dan antioksidan eksogen yang berasal dari makanan (32). Diet antioksidan eksogen mencegah kerusakan seluler melalui reaksi yang dilakukan oleh radikal bebas.

Aktivitas benalu teh sebagai antioksidan yang terkandung dalam ekstrak ditandai dengan daya mereduksi kaliumferisianida $\left[\mathrm{K}_{3} \mathrm{Fe}(\mathrm{CN})_{6}\right]$, menghambat oksidasi asam linoleat, kemampuan eliminasi terhadap $\mathrm{H}_{2} \mathrm{O}_{2}$ (33). Uji aktivitas antioksidan menggunakan radikal bebas 1,1difenil-2-pikrilhidrazil (DPPH), dilakukan pada ekstrak daun benalu teh S. oortiana (ekstrak n-heksan, etilasetat, metanol, dan air). Aktivitas antioksidan ditentukan dengan nilai IC50 (ug/ml). Berdasarkan kurva konsentrasi (ug/ml) dengan peredaman radikal bebas (\%) terlihat bahwa vitamin $\mathrm{C}$ sebagai kontrol positif memiliki potensi antioksidan tertinggi dengan nilai IC50 65,51, artinya dengan konsentrasi $65,51 \mathrm{ug} / \mathrm{ml}$ dapat menghambat $50 \%$ kerja radikal bebas DPPH. Semakin rendah nilai IC50 semakin tinggi potensi antioksidannya. Nilai IC50 ekstrak nheksan adalah 697,68 ug/ml, ekstrak etilasetat adalah $617,03 \mathrm{ug} / \mathrm{ml}$, ekstrak metanol 93,59 ug/ml, dan ekstrak air adalah 121,17 ug/ml (33).

Antioksidan adalah senyawa kimia yang dapat menyumbangkan satu atau lebih elektron kepada radikal bebas, sehingga radikal bebas tersebut dapat dihambat. Berdasarkan sumber perolehannya ada dua macam antioksidan, yaitu antioksidan alami dan antioksidan buatan (34). Tubuh manusia tidak mempunyai cadangan antioksidan dalam jumlah berlebih, sehingga jika terjadi paparan radikal berlebihan, maka tubuh membutuhkan antioksidan eksogen. Adanya kekhawatiran akan kemungkinan efek samping yang belum diketahui dari antioksidan sintetik menyebabkan antioksidan alami menjadi alternatif yang sangat dibutuhkan $(35,36)$. Antioksidan alami mampu melindungi tubuh terhadap kerusakan yang disebabkan spesies oksigen reaktif, mampu menghambat terjadinya penyakit degeneratif serta mampu menghambat peroksidase lipid pada makanan. Antioksidan alami umumnya mempunyai gugus hidroksi dalam struktur molekulnya (36).

Upaya pencegahan dan pengobatan penyakit jantung dan pembuluh darah sampai saat ini belum banyak diketahui, karena masih banyak permasalahan patogenesanya yang belum terungkap. Salah satu diantaranya adalah terjadinya modifikasi LDL akibat dilepaskannya radikalradikal bebas oleh sel endotel dan sel otot polos dinding vaskuler. Senyawa LDL teroksidasi membentuk ox-LDL (toksik LDL). Hal ini dapat dicegah dengan adanya antioksidan. Secara empiris tumbuhan benalu teh telah banyak dimanfaatkan sebagai obat tradisional terhadap berbagai penyakit dan mempunyai efek sebagai antioksidan.

Status antioksidan dalam tubuh dapat diamati dalam berbagai parameter, misalnya aktivitas enzim superoksida dismutase (SOD), katalase, glutation peroksidase seluler, kadar MDA, vitamin C, vitamin E, vitamin A plasma, dan lain-lain. SOD mengkatalisis reaksi dismutasi dari radikal anion superoksidase menjadi $\mathrm{H}_{2} \mathrm{O}_{2}$, sedangkan katalase dan glutation peroksidase mengubah $\mathrm{H}_{2} \mathrm{O}_{2}$ menjadi $\mathrm{H}_{2} \mathrm{O}$. Oleh sebab itu, kesempurnaan kerja sistem enzim antioksidan diperankan oleh ketiga enzim tersebut. Antioksidan seluler tidak dapat bekerja secara individual tanpa dukungan asupan antioksidan sekunder dari bahan pangan. Makin tinggi asupan antioksidan eksogen, makin tinggi pula status antioksidan endogen (37).

Ekstrak benalu teh spesies Scurrula atropurpurea mengandung 16 bahan bioaktif yang terdiri atas enam senyawa asam lemak, dua santin, dua glikosida flavonol, satu glikosida monoterpen, satu glikosida lignan, dan empat flavon (13). Kemampuan benalu teh kemungkinan menghambat kerusakan oksidatif yang disebabkan oleh radikal bebas berkaitan dengan aktivitas bahan aktif pada benalu teh sebagai antioksidan. Daun dan batang tanaman ini mengandung alkaloid, flavonoid, glikosida, triterpen, saponin, dan tanin yang berperan sebagai antioksidan (38). Potensi flavonoid sebagai antioksidan dan kemampuannya mengurangi aktivitas radikal hidroksi, anion superoksida, dan radikal peroksida lemak menjadikan flavonoid berperan penting dan sangat erat kaitannya dengan proses dan epidemiologi penyakit $(39,40)$.

Pada imunitas nonspesifik hewan mengaktivasi makrofag untuk memproduksi agen penghancur produk mikroba dengan cara mensintesis nitric oxyde synthase. Enzim ini menggunakan NADPH dan oksigen untuk mengaktivasi Larginin untuk memproduksi NO dan sitrulin Nitrit oksida merupakan molekul yang penting yang mempengaruhi sistem kardiovaskuler. Nitrit oksida merupakan senyawa yang bersifat toksik dan berumur pendek, berupa molekul gas yang diproduksi oleh enzim inducible NO synthase, dengan cara mengubah asam amino arginin menjadi NO dan sitrulin (41). Molekul NO berperan penting sebagai regulator kardiovaskuler, meningkatkan tekanan darah, diproduksi oleh neuron dan makrofag. Nitrit oksida 
memiliki jumlah elektron ganjil dan sebagai radikal bebas, molekul ini relatif stabil namun bereaksi cepat bila bertemu dengan senyawa yang mengandung elektron yang tidak berpasangan, misalnya molekul oksigen, anion superoksida dan ion logam (42). Flavonoid telah diketahui sebagai antibakteri, antiviral, antiinflamasi, antialergi, antimutagenik, antitrombotik, dan aktivitas vasodilatasi $(39,40)$.

Secara in vitro, flavonoid telah terbukti mempunyai efek biologis yang sangat kuat, sebagai antioksidan flavonoid dapat menghambat penggumpalan keping-keping darah, merangsang produksi NO yang menyebabkan relaksasi pembuluh darah, dan untuk menghambat pertumbuhan kanker. Disamping berpotensi sebagai antioksidan flavonoid sebagai penangkap radikal bebas, juga memiliki sifat seperti hepatoprotektif, antitrombotik, antiinflamasi, dan antivirus. Sifat antiradikal flavonoid terutama terhadap radikal hidoksil, anion superoksida, radikal peroksil, dan alkoksil (42). Flavonoid juga berperan menghambat aktivitas enzim siklooksigenase dan lipoksigenase, merupakan mediator inflamasi dengan cara menghambat pelepasan asam arachidonat yang merupakan komponen kemotaktik.

Secara epidemiologi ditunjukkan bahwa mengonsumsi flavonoid yang terdapat pada makanan dan minuman seperti teh, anggur akan mengurangi resiko penyakit jantung koroner, flavonoid juga mempunyai efek antitrombus dan antiinflamasi sehingga mampu menurunkan resiko penyakit jantung (43). Penelitian secara epidemiologi pada masyarakat Belanda yang mengkonsumsi flavonoid seperti teh, apel dan bawang putih akan menurunkan resiko penyakit jantung $68 \%$. Beberapa penelitian di Inggris dan Amerika menunjukkan korelasi antara flavonoid dengan penurunan resiko penyakit jantung (44).

\section{Efek Benalu Teh pada Perbaikan dan Restorasi Fungsi Endotel}

Endotelium yang sehat mengontrol keseimbangan antara vasokonstriksi dan vasodilatasi, promosi dan inhibisi pertumbuhan sel, prokoagulasi dan antikoagulasi, proinflamasi dan antiinflamasi, serta oksidasi dan antioksidasi. Endotelium melakukan respon baik terhadap rangsangan fisik (misalnya shear stress) maupun terhadap senyawa kimia yang beredar dalam darah dengan mensintesis dan melepaskan banyak senyawa biologi aktif. Zat-zat ini berdifusi ke arah dinding pembuluh darah untuk mempengaruhi otot polos vaskuler dan sel-sel mononuklear atau juga dapat berdifusi ke arah lumen yang dapat mempengaruhi permukaan lumen pembuluh darah (45). Senyawa-senyawa tersebut selanjutnya terlibat dalam pengaturan tonus vaskular dan mempertahankan fluiditas dari darah. Disfungsi endotel diartikan sebagai ketidakseimbangan antara faktor-faktor relaksasi dan kontraksi, antara faktor-faktor antikoagulan dan prokoagulan, antara faktor-faktor yang menghambat pertumbuhan dan proliferasi dengan yang memacu pertumbuhan dan proliferasi sel $(46,47)$. Pemberian amylodipin dan vitamin $\mathrm{C}$ secara terus menerus dalam jangka waktu lama akan memperbaiki fungsi endotel pada pasien hipertensi (48). Ketidakseimbangan ini dapat terjadi oleh karena berkurangnya sintesis atau pelepasan faktor-faktor protektif (misalnya EDRF, prostasiklin) atau bertambahnya sintesis atau pelepasan faktor-faktor kontraksi, prokoagulan, pemacu pertumbuhan (growth promotors) atau dapat juga kedua-duanya (49). Beberapa faktor resiko yang dapat menyebabkan terjadinya disfungsi endotel salah satunya adalah peningkatan tekanan darah (45).

Endothelial Progenitor Cell (EPC) dapat memperbaiki kondisi-kondisi penyakit yang diawali dengan kerusakan sel-sel endotel, baik secara anatomis/struktural maupun fungsional, melalui mekanisme neovaskularisasi. Para peneliti menyakini bahwa di dalam sumsum tulang dan aliran darah tepi terdapat sel-sel yang mampu membelah dan berdiferensiasi menjadi sel-sel endotel dan memperbaiki jaringan iskemik akibat rusaknya dinding pembuluh darah. Sel-sel ini disebut EPC, ada dua mekanisme EPC dalam neovaskularisasi yaitu melalui reendotelialisasi atau neovaskularisasi. Pada cara pertama sangat tergantung pada derajat kerusakan atau iskemia jaringan, sumber EPC maupun cara pemberian (misalnya melalui pemberian intravenous setelah ekspansi ex vivo atau memobilisasi EPC dari sumsum tulang dengan sitokin atau growth factor). Neovaskularisasi bergantung pada pelepasan faktor proangiogenik, misalnya VEGF atau faktor-faktor kemotaksis seperti SDF-1 atau CXCR4 (50).

Proses angiogenesis memegang peranan penting. Sitokin, seperti basic fibroblast growth factor (bFGF) dan vascular endothelial growth factor (VEGF) telah terbukti berhubungan dengan proses angiogenesis. Proses angiogenesis pertama, adanya sinyal biologis mengaktifkan reseptor pada sel endotel pembuluh darah. Kedua, sel-sel endotel mulai melepaskan enzim protease yang mendegradasi membran basemen untuk memungkinkan sel endotel melepaskan diri dari sel induk. Sel-sel endotel kemudian berkembang ke dalam matriks padat sekitarnya, menuju sumber stimulus angiogenik. Sel-sel endotel bermigrasi bersama-sama, dengan menggunakan molekul adhesi (50). Kajian ini menunjukkan bahwa flavonoid dari benalu teh diduga mampu memperbaiki disfungsi endotel melalui mekanisme reendotelisasi. Flavonoid dari herbal Epimedii menyebabkan diferensiasi osteogenesis pada mesenkim stem sel bone marrow manusia (51).

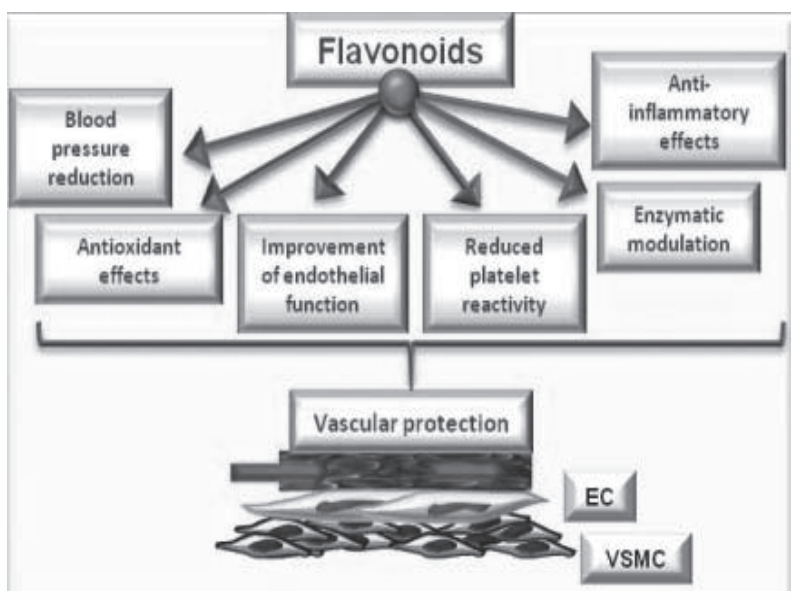

Gambar 3. Peran flavonoid terhadap proteksi vaskular (52)

Kajian pustaka ini menunjukkan bahwa mekanisme kerja benalu teh pada pembuluh darah terjadi pada organ target otot polos dan endotel. Zat aktif tersebut mampu berdifusi secara langsung dan mensintesa NO 
dalam endotel dan otot polos selanjutnya merangsang guanylate cyclase untuk membentuk cGMP sehingga terjadi vasodilatasi. Diduga benalu teh bersifat antagonisme kompetetif reseptor $\alpha_{1}$ sehingga tidak terjadi aktivasi reseptor $\alpha_{1}$ Benalu teh menghambat kanal $\mathrm{Ca}^{2+}$ sehingga tidak terjadi peningkatan $\mathrm{Ca}^{2+}$ intrasel dan terjadi defosforilasi MLC akhirnya tidak terjadi kontraksi otot arteri $(10,19,25,53)$. Flavonoid benalu teh dalam hal ini

\section{DAFTAR PUSTAKA}

1. Ge T, Hughes H, Junquero DC, Wu KK, Vanhoutte PM, and Boulanger CM. Endothelium-Dependent Contractions are Associated with Both Augmented Expressionof Prostaglandin $H$ Synthase-1 and Hypersensitivity to Prostaglandin $\mathrm{H}_{2}$ in the SHR Aorta. Circulation Research. 1995; 76: 1003-1010

2. Goodman and Gilman's. The Pharmacological Basis of Therapeutics. 11th edition. New York: McGraw Hill Companies Inc.; 2006 ; p. 1-15.

3. World Health Organization. National Policy on Traditional Medicine and Regulation of Herbal Medicine. Report of WHO Global Survey. Geneva: World Health Organization Press; 2005.

4. Blumenthal M. The Complete German Commision $E$ Monographs: Therapeutics Guide to Herbal Medicines. Texas: Integrative Medicine Communications; 1998.

5. Loeper ME. Mistletoe (Viscum album L). (Online) 1999; 1-17. http://www.mcp.edu/herbal/ default.htm

6. Kirana C, Mastuti R, Widodo MA, Sumitro SB, dan Indriyani S. Komposisi Bahan Bioaktif Benalu. Jurnal Ilmu-Ilmu Teknik (Engineering). 2001; 13: 193-203.

7. Khosh F and Khosh M. A Natural Approach to Hypertension. Alternative Medicine Review. 2001; 6(6): 590-600.

8. Thompson K. Mistletoe Mythology and Medicine. Journal Ethnopharmacology. 2003; 27:1-7.

9. Eno AE, Ibokette UE, Ofem OE, et al. The Effects of a Negerian Specie od Viscum Album (Mistletoe) Leaf Extraction on the Blood Pressure of Normotensive and DOCA_Induced Hypertensive Rats. Nigerian Journal of Physiological Sciences. 2004; 19 (1-2): 33-38.

10. Athiroh N, Widodo MA, dan Widjajanto E. Efek Scurulla oortiana (Benalu Teh) dan Macrosolen javanus (Benalu Jambu Mawar) terhadap Kontraktilitas Pembuluh Darah Arteri Ekor Tikus Terpisah dengan atau tanpa Endotel. [Tesis]. Universitas Brawijaya, Malang. 2000.

11. Mensah JK, Okoli RI, Turay AA, and Ogie-Odia EA. Phytochemical Analysis of Medicinal Plants Used for the Management of Hypertension by Esan People of Edo State, Nigeria. Ethnobotanical Leaflets. 2009; 13: 1273-1287.

12. Simanjuntak PT, Parwasi LE, Lenny S, Tamat, dan Murwani R. Isolasi dan Identifikasi Senyawa quercetin mampu bekerja langsung pada otot polos pembuluh arteri dengan menstimulir atau mengaktivasi EDRF (Endotheliun Derived Relaxing Factor) sehingga menyebabkan vasodilatasi. Flavonoid tanaman teh yaitu polifenol dapat meningkatkan aktivitas dari Nitric Oxide Synthase (NOS) pada sel endotel pembuluh darah. Benalu teh mampu menghambat kontraksi arteri karena adanya peran endotel pembuluh darah.

Antioksidan dari Ekstrak Benalu Teh Scurulla oortiana (Korth) Danser (Loranthaceae). Jurnal IImu Kefarmasian Indonesia. 2004; 2(1): 6-9.

13. Ohashi K, Winarno H, Mukai M, et al. Cancer Sell Invasion Inhibitory Effects of Chemical Constituents in the Parasitic Plant Scurulla artropurpurea (Loranthacea). Chemical and Pharmaceutical Bulletin. 2003; 51 (3): 343-345.

14. Winarno $H$, Ohashi $K$, Mukai $M$, Simanjuntak $P$, dan Shibuya H. Uji Bioaktivitas terhadap Invasi Sel Kanker dan Beberapa Senyawa Flavonoid, Santin, Terpen, dan Ligan yang Diisolasi dari Benalu Teh (Scurulla artropurpurea) Loranthacea. Prosiding Seminar dan Pameran Nasional Tumbuhan Obat Indonesia XXIV. Pusat Studi Biofarmaka. LP-IPB. Darmaga. Bogor, 2003; hal. 141-149.

15. Murphy KJ, Chronopolous AK, Singh I, et al. Dietary Flavanols and Procyanidin Oligomers from Cocoa (Theobroma cacao) Inhibit Platelet Function. American Journal of Clinical Nutrition. 2003; 77(6): 1466-1473.

16. Stavric B and Matula TI. Flavonoids in Foods. Their Significance for Nutrition and Health. In: Ong AHS (Ed). Lipid Soluble Antioxidant: Biochemistry and Clinical Applications. Basel: Birkhauser Verlag; 1992; p. 274294.

17. Schmitt VM and Dirsch VM. Review Modulation of Endothelial Nitric Oxide by Plant-derived Product. Nitric Oxide: Biology and Chemistry. 2009; 21(2): 7791.

18. McNeill JR and Jurgens TM. A Systematic Review of Mechanisms by Which Natural Products of Plant Origin Evoke Vasodilation. Canidian Journal of Physiology and Pharmacology. 2006; 84(8-9): 803821.

19. Widodo MA. Memahami Struktur dan Fungsi Endotel untuk Menjelaskan Patogenesa Penyakit KardioVaskular. Pidato Pengukuhan Jabatan Guru Besar dalam Ilmu Farmakologi Fakultas Kedokteran Universitas Brawijaya. Malang, 1998; hal. 6, 10-11.

20. Anter E, Thomas SR, Schulz E, Shapira OM, Vita JA, and Keaney JF. Activation of Endothelial Nitric-Oxide Synthase by the p38 MAPK in Response to Black Tes Polyphenols. The Journal of Biological Chemistry. 2004; 279: 46637-46643.

21. Jochmann N, Lorenz M, Krosigk AV, et al. The Efficacy of Black Tea in Ameliorating Endothelial Function is Equivalent to that of Green Tea. British Journal of Nutrition. 2008; 99: 863-868. 
22. Soares de Moure R, Costa Viana FS, Souza MA, et al. Antihypertensive, Vasodilator and Antioxidant Effect of a Vinifera Grape Skin Extract. Journal of Pharmacy and Pharmacology. 2002; 54: 1515-1520.

23. Negishi H, Xu JW, Ikeda K, et al. Black and Green Tea Polyphenols Attenuate Blood Plessure Increases in Sroke-prone Spontaneously Hypertensive Rats. Journal of Nutrition. 2004; 134: 38-42.

24. Capasso R, Aviello G, Romano B, Atorino G, Pagano E, and Borelli F. Inhibitory Effect of Quercetin on Rat Trachea Contractility In Vitro. Journal of Pharmacy and Pharmacology. 2009; 61 (1): 115-119.

25. Mojiminiyi FBO, Owolabi ME, Igbokwe UV, and Ajagbonna P. The Vasorelaxant Effect of Viscum Album Leaf Extract is Mediated by CalciumDependent Mechanism. Nigerian Journal of Physiological Sciences. 2008; 23(1-2): 115-120.

26. Aziza L. Peran Antagonisme Kalsium dalam Penatalaksanaan Hipertensi. Majalah Kedokteran Indonesia. 2007; 57: 1-6.

27. Yoshizumi M, Tsuchiya K, Kirima,K, Kyaw M, Suzaki Y, and Tamaki T. Quercetin Inhibits Shc- and Phosphatidylinositol 3-Kinase- Mediated c-Jun NTerminal Kinase Activation by Angiotensin II in Cultured Rat Aortic Smooth Muscle Cells. Molecular Pharmacology. 2001; 60(4): 656-665.

28. Actis-Goretta L, Ottaviani JL, and Fraga CG. Inhibition of Angiotensin Converting Enzyme Activity by Flavonol-Rich Foods. Journal of Agriculture and Food Chemistry. 2006; 54: 229-234.

29. Grassi D, Aggio A, Onori L, et al. Tea, Flavonoids, and Nitric Oxide-Mediated Vascular Reactivity. The Journal of Nutrition. 2008; 138(8): 1554-1560.

30. Lakhanpal P and Rai DK. Role of Quercetin in Cardiovescular Diseases. Journal of Medical. 2008; 3(1): 31-49

31. Winarsi H. Antioksidan Alami dan Radikal Bebas. Potensi dan Aplikasinya dalam Kesehatan. Yogyakarta: Kanisius; 2007.

32. Manampiring AE, Asyari SR, dan Arifin Z. Pengaruh Kebiasaan Mengonsumsi Tempe dan Kebiasaan Mengonsumsi Ikan terhadap Kadar Malanoldehida dan Vitamin E Plasma Darah. Sains Kesehatan. 2001; 14(2): 208-219.

33. Leswara DN dan Kartini. Perbandingan Daya Antioksidan Beberapa Jenis Benalu Menggunakan Metode Spektrofotometri. Warta Tumbuhan Obat Indonesia. 1998; 4: 10-12.

34. Dalimartha S dan Soedibyo M. Awet Muda dengan Tumbuhan Obat dan Diet Suplemen. Jakarta: Trubus Agriwidya; 1999; hal. 36-40.

35. Rohdiana D. Aktivitas Daya Tangkap Radikal Polifenol dalam Daun Teh. Majalah Jurnal Indonesia. 2001; 12(I): 53-58.

36. Sunarni T. Aktivitas Aktioksidan Penangkap Radikal Bebas Beberapa Kecambah dan Tanaman Familia Papilionaceae. Jurnal Farmasi Indonesia 2. 2005; 2: 53-61.

37. Winarsi H. Efek Minuman Fungsional yang Disuplementasi Isoflavon Kedelai dan Zn terhadap
Profil Lipid dan Produk MDA Plasma Wanita Premenopause. Prosiding Seminar Nasional PBBMI Peran Blokimia dalam Biologi Molekuler dalam Eksplorasi dan Pemanfaatan Sumber Daya Hayati Berkelanjutan. Yogyakarta, 2004.

38. Windari FI dan Rahajoe JS. Keanekaragaman Jenis Benalu di Pulau Jawa. Warta Tumbuhan Obat Indonesia (The Journal on Indonesian Medicinal Plant). 1998; 4(4): 25-29.

39. Larbier $\mathrm{M}$ and Loeclerco B. Nutrition and Feeding Poultry. Nottingham: Nottingham University Press; 1992; p. 1-5.

40. Miller AL. Antioxidant Flavonoids: Structure Function. Function and Clinical Usage. Journal Flavonoid. 1996; 1:1-7.

41. Becker WM, Kleinsmith LJ, and Hardin J. The Word of the Cell. Biologiva Plantarum. 2003; 47(4): 534.

42. Campbell PN and Smith AD. Biochemistry Illustrated. 4th edition. Philadhelpia: Churchill Livingstone: 2000; p. 21-26.

43. Sherene M, Shenouda, and Vita JA. Effect of FlavonoidContaining Beverages and EGCC on Endothelial Function. Journal of the American College of Nutrition. 2007; 26(4):366S-372S.

44. Barrier TA, Hatcher L, and Sasser HC. Potential Benefits on Impairment of Endothelial Function after a High-fat Meal of 4 Weeks of Flavonoid Supplementation. Evidence-Based Complementary and Alternative Medicine. 2011; 2011:1-6.

45. Parmley WW. Evolution of Angiotensin-Converting Enzyme Inhibition in Hypertension, Heart Failure, and Vascular Protection. American Journal of Medicine. 1998; 105: 275-315.

46. De Meyer GRY and Herman AG. Vascular Endothelial Dysfunction. Progress in Cardiovascular Diseases. 1997; 39(4): 325-342.

47. Rubanyi GM. The Role of Endothelium in Cardiovascular Homeostasis and Disease. Journal of Cardiovascular Pharmacology. 1993; 22: S1-S14.

48. On YK, Kim CH, Sohn DW, Oh BH, Lee MM, and Park YB. Improvement of Endothelial Function by Amlodipine and Vitamin $C$ in Essential Hypertension. Korean Journal of Internal Medicine. 2002; 17(2): 131-137.

49. Pepine C. Endothelial Dysfunction and its Role in the Cycle of Cardiovascular Disease. Canadian Journal of Cardiologi. 1998; 14: 5-7.

50. Carmeliet P. Angiogenesis in Health and Deseases. 2003; 9(6); 653-660.

51. Zhang JF, Li G, Chan $\mathrm{CY}$, et al. Flavonoids of Herba Epimedii Regulate Osteogenesis of Human Mesenchymal Stem Cells through BMP and Wnt/BetaCatenin Signaling Pathway. Molecular and Cellular Endocrinology. 2010; 314(1): 70-74.

52. Grassi D, Desideri G, and Ferri C. Flavonoid: Antioxidants Against Atherosclerosis. Nutrients. 2010; 2:889-902.

53. Athiroh N. Kontraktilitas Pembuluh Darah Arteri Ekor Tikus Terpisah Dengan atau Tanpa Endotel Setelah Pemberian Esktrak Scurulla oortiana (Benalu Teh). Jurnal Berkala Hayati Edisi Khusus 3D. 2009; 31-34. 